\title{
The Use of the Drama Pedagogical Method in the Training of Cultural Project Managers
}

\section{Szabolcs Zalay*}

\begin{abstract}
The universities are traditionally elitist bulwarks. How do they counter this image? I would like to present a special andragogy strategy which I apply in university level education, in the Cultural Project Managers' training against poverty and social exclusion in the Institute of Cultural Studies at the University of Pécs. I demonstrate the application of drama pedagogy method in the course of the training. We have more and more experience concerning the fact that the Hungarian "drama pedagogy school", that became stronger in recent decades, has introduced and developed effective methodological frameworks to realize constructive pedagogy able to create more efficient pedagogical situations than the traditional education methods. This means that today's Hungarian drama pedagogy possesses the qualities which enable to answer many of the challenges mentioned above.
\end{abstract}

Key words: responsibility, culture, training, drama pedagogy, constructivism.

In the communication training of cultural project managers we are able to get extremely valuable feedback on the behavior that defines professional success in future. Below, I discuss the training structure, which will greatly help cultural professionals to develop an attitude aimed at battling poverty and social exclusion. I explore the nuances of the training method, during which, inter alia, with the aid of communication acts performed in the roles, the participants can examine real communicative situations and conflicts (Zalay, 2002). The attitude system of the group unfolds, and as a result of the controlled process management, the participants will have discipline, understand their need to take part in exercises which generate tension. It is possible to unveil the sources of problems, to propose solutions to them, or indirectly generate the need of the participants' change. As a consequence, communication skills can develop optimally and a significant improvement in the

\footnotetext{
* Szabolcs Zalay, PTE FEEK Institute of Culture, University of Pécs, Hungary; zalaysz@freemail.hu
} 
choice of communication strategies aimed at combating poverty and social exclusion is projected which will be reflected in further work.

\section{Challenges of our time}

Today, when you can learn in new ways, new methods should be taught as well. In the era of the IT revolution we have a speed challenge: anyone who slows down, will be left behind, will be boring and will be ignored. Intense experiences are required by the students. There is a quantitative challenge: everyone can have access to everything, if they are lucky, or if they want, but that is why students need quality experiences. There is a democratic challenge: students require democratic atmosphere and publicity. Finally, there is a global challenge: everyone is in a competition and at the same time is at risk. Therefore, we, as teachers, are expected to develop community responsibility competences and competitiveness. If we want to respond to these challenges, an educational paradigm shift and methods, which offer lively alternatives and give experiences preserved in the long-term memory of the participants of the learning process, are required (Zalay, 2008). Today's Hungarian drama pedagogy promises to be a method of such a paradigm shift, and offers an excellent opportunity for the transaction of different kinds of educational trainings.

Drama pedagogy, its current Hungarian version, bears the marks of the constructivist pedagogy, especially the so-called "school drama" (Zalay, 2006). It is considered to be the pedagogy which can evoke significant learning experiences. Indeed, the essence of its mechanisms of action can be recognized by learning that occurs at the deeper meanings subjectively understood by the level of experience of the effect that occurs in the discovery, which personalizes their problems through the study of a fictitious medium. At the same time, the constructive drama operates with deliberately planned but high-level-autonomy collective learning systems, thus developing a strong degree of openness, empathy and the ability to understand others in the community due to the synergistic collaboration experienced by the participants. All these experiences will be indispensible for future cultural project manager in their work.

\section{The developmental opportunities of communication training}

The training of cultural project managers, tried out in the Institute of Culture of the Faculty of Adult Education and Human Resources Development at the University of Pécs, have the overall aim of improving participants' communication skills and raising interactions awareness. This learning process, compared with normal school processes, happens in a much more intensive way, by providing extra energy in practice, the "novelty" of the tasks performed, playfulness and team spirit. The role of a trainer is 


\section{Acta Technologica Dubnicae}

volume 1, 2011, issue 2

quite unique as well, not located above the group, not taking on a teaching role. A trainer is rather a moderator, keeping the process in hand, adapting the follow-up tasks to the group's "state", describing their rules, but making no judgement. The "work" progresses within the framework of shared goals, expectations and rules not directed "from above", as the trainer is helping participants in the joint planning. The group members are equal, forming a circle; no one is cast out, forming a closed shape, so theoretically everyone can be in constant contact with the others.

It depends largely on the trainer's competence and professional experience to get the group to an appropriate level of confidence, which is the key to the whole training. At the same time the trainer must proceed with caution, because the occurrence of rather intimate questions too early can lead to alienation of some members of the group and can lead to failure of the group. Learning, itself, is based on continuous activity and active participation. The group members participate in a series of roleplaying tasks which is processed through event discussions.

This will increase the training efficiency - via practices and situations the participants get in strong mental and emotional effects, and these effects are strongly entrenched through the experiences of individuals. The continuous, active participation puts the group members into a continuous interaction, which on the one hand develops cooperation skills, which may improve communication skills, on the other hand it may affect their personal self-esteem, identity development, and the improvement of skills can also promote more conscious, flexible thinking.

All this depends on individual participation and success of the training. Working together usually strengthens the relationships between group members, may affect the individual's openness towards others, increase the tolerance, the level of trust, the participants can learn about consensus building strategies through appropriate exercises. The participants can get feedback on the strengths and weaknesses of working together with people. They may find answers to what extent they can affect people, or they can influence the extent of their organization skills, and realize in what areas they might need to increase efficiency. By increasing people' skills, judging people by the first impression can become avoidable (Várnagy, 2003), and this will also be an important condition for the successful and exclusion-free cultural broker work.

The tasks solved together and individually, help identify the harmony between the group and individual performance. The team members learn what they are usually seen like, what the others and outsiders say about them, and through the participation in training situations their self-image expands to a new dimension. Thus their self- 


\section{Acta Technologica Dubnicae}

volume 1, 2011, issue 2

knowledge increases, their personal constraints and opportunities also become more conscious. In exercises the participants develop communication skills, become more aware of verbal and nonverbal communication in different application forms, of the ability to recognise different meanings of the voice, the look, the facial expression and posture, and via this they develop better understanding of other people.

Success or failure during interesting and specific tasks and practices encourages the participants to think more flexibly. Thus the participants can get to know the other members in different ways. Good atmosphere and well-executed training using deep impressions, not only improve individual communication skills, but the participants go through the development of personal skills and self-perception, thinking, social ratios, and they improve human relations by shaping each other.

\section{Special features of constructive drama pedagogy training}

The communication training based on drama pedagogy features comes especially from the developed professional background of the "drama" linked to conscious applications. According to one of the most notable Hungarian drama pedagogue, Erik Szauder, the main element of the use of drama in pedagogy is the examination of individual and social values and Foucault's cultural content analysis (Foucault, 1986) by the means called "the problemization of the idea". In other words: drama is increasing personal knowledge of critical behaviour, obviously in a fictional situation but, apart from this, it has all the elements of reality (Szauder, 2001, p. 31).

The main features of this method come indeed from its nature of being art-pedagogy, because it can operate with the developed methods of theatre and drama. Although, as Erik Szauder (2001) puts it: "The application of drama in education, the situation is slightly different, because the participants in the process created are both actors and audience". The dramatic happening does not have, unlike written drama, a prerecorded text, regardless of the intentions of the participants (i.e., text, action, and relation-system). The participants in the drama happening are "forced" to manifest cognitive and social activity in the situations which become experienceable and understandable, only if the participants have actively summon them. The jointly created situations, besides events of social and emotional content, of course, may also convey a lot of factual information as well. They are, however, unlike the "textbooktasting", alienated, decontextualized way of conveying, and they appear in the contextual framework (Szauder, 2001, p. 31). That is, in contrast to the situation often happening during traditional situation training exercises. Role-play taking place in the dramatic context does neither means taking-off from the reality nor it can give room to irresponsible "playing". On the contrary: it makes the continuous correlation of the 


\section{Acta Technologica Dubnicae}

volume 1, 2011, issue 2

laws of reality and the reality of fiction inevitable, because despite the fact that fiction in some respects may terminate the framework of reality (e.g., linear timeliness or spatial constraints), the internal logic has to align to real-life experiences (Szauder, 2001, p. 32).

Laszló Kaposi, the president of the Hungarian Drama Society and one of the creators of the Hungarian "drama pedagogy school", believes that educational drama differs from other dramatic processes in the fact that the determining elements of created situations (space, time, characters, relationships, etc.) are knowingly regulated to serve educational purposes. Contrary to the generally more loosely structured, and therefore less controllable dramatic games; the administration of "situational practices" and the theatre, uncertain in its effects, where all these elements are much more restricted, is more difficult (Kaposi, 2004).

From all this comes the key to the effectiveness of communication training inspired by the drama: aside of the practicality of educational benefits of traditional training with the help of the internal laws of drama through the use of their conscious mobilization and management of the artistic experience and all this located in a verifiable, protected context. In this way, it does not expose the participant to the doubtful experience of "fooling around", and with offered "openness" - ideally - does not the abuse situations left uncontrolled as a result.

The best training, however, spontaneously develops according to the features, composition and mood of those present, and also to the teacher's empathy. Even the most thorough planning may not be good enough, if we are not ready to improvise. And so, all times vary, as two drama lessons cannot be the same. Because of this and the always exciting opportunity of making a new contact makes communication training exciting and adds opportunities of catharses.

If, during the training, we consciously use the above-mentioned methods of drama pedagogy, taking the advantage of educational benefits analysed building on the professional bulwarks of "drama", we can get to the very efficient development of communication. All this plays an important role in the communication training of cultural project managers inspired by the drama pedagogy.

\section{The dramaturgy of the learning process}

If we want to know how the learning process takes place at the deeper levels of the training and what a secret is the effect mechanism of drama pedagogical training, we definitely have to look at the "internal dramaturgy" of the training. By this we mean 


\section{Acta Technologica Dubnicae}

volume 1, 2011, issue 2

the really dynamically active ingredients, which carry the potential of creating the meaning. Coming from the classical terminology, here we have dramatic action and diction, in teaching drama the so-called "convention" that operates and regulates the whole dramatic structure, creating the "motivic" network of a constructive (learning and teaching) drama and training; and, last but not least, the cathartic effect of their theatrical means by which the training can really influence the arts and experiential education.

Two types of action of dramatic manifestation should be taken into account, and exploring their relational system provides an explanation for the "special" nature of the opportunities of drama learning (Bolton, 1996). One is the so-called "external action" which is created by the collision of two specific worlds. Therefore the situational actions of the players are concrete actions and actions of "another world" at the same time. The objects are both specific objects but they bear symbolic meaning as well. The quality of the dramatic action is determined by the way of connectivity between the two contexts. Depending on the extent to which a participant perceives and understands the role played, the fictional world unfolds its real meaning to him. The training seems only an action, in reality, it is thinking embedded in the action aimed at the meaning creation, with the interaction of two mediating contexts (Bolton, 1996, p. 22). The two types of meaning originated from external action are: a person practicing skill exercises and bringing these skills to the surface, which is needed to achieve the specific role. The knowledge can evolve and develop during the game, as an effect of moral experience it can be identified and filtered out. This is an inductive process taking place. During external actions, on the basis of actual experiences, the general logic contents can be manifested in the personality.

However, the training of the learning process is more relevant in terms of what happens during the "internal action". During the presentation which is the result of referencing to each other in two contexts, the underlying content that may be produced and become adaptive in the point of view of learning, which can be materialized only in the action. In fact there is no new knowledge, but rather the mobilization of prior knowledge. In other words, the game provides opportunities for the use of such knowledge, which has not yet been activated by the personality. The "internal action" moves from the general direction towards the specific one, from the theme towards the action, which is just the opposite of the "external action" moving from the specific action towards the general direction (Bolton, 1996, p. 27). On this basis, we can state that there is a lot of learning potential in the training of drama based principle both in the field of skills and knowledge. The biggest change yet can occur in the deeper meanings, the meanings subjectively understood. 


\section{Acta Technologica Dubnicae}

volume 1, 2011, issue 2

The subjective meanings are created by the emotional attitudes which participants manifest in their name and express during situations created (Telegdy, 2006). The requirements of the learning process are (Bolton, 1996): the joint participation, the emotional experiences used in a new quality, overshadowing "raw emotion" and the content of personal appearance and common content appropriate to the training situations. The stages of change in understanding resemble the typical constructivist model of learning: confirmation, clarification and change. They occur variably, often sliding into each other during training sessions.

The essence of "internal action" is that new experiences incorporate into the existing experience and knowledge structure, if the participants are given the opportunity to build bridges between the known and unknown content by means of discovering new meanings and processing experiences (Neelands, 1994). Therewith the task of the trainer is to find the way to mobilize the existing knowledge and to establish a direct connection to the material examined. This can be achieved by giving "a sort of a focusing lens" into the hands of the participants (Neelands, 1994). Such an image properly symbolises the essence of the training mode of action that generates a situational learning processes, in which the learning experiences become intensely experienceable and interpretable; by means of consciously controlled adaptive operation of a dynamic impact through the artistic means.

Obviously, because of their artistic character, action and diction should complement each other. "Speeches" within the training have a dual function. On the one hand, in connection with the "external actions" they develop communication skills, on the other hand during the "internal action" via experiencing the joy of expression they will become active parts of creation as a learning process. However, besides the scenes there are discussions, which are at least as important as they deal with coordination, questions, possible arguments and work by means of evaluation. The "language" of these trainings is clearly characterised by constructive communication as the trainer continuously operates in his "vocalizing" role and does not do so in a reckoning tone, but in the spirit of linguistic construction based on reciprocity. Such an example may be of strong effect to the group dynamic processes, since the learning process, especially the long-term educational process, develops a synergistic network of communication (Zalay, 2004). Moreover, the reflective nature of drama has a special role during which the language will be put forward by meta-cognitive aspects.

\section{Conclusions}

The constructive mode of action in drama pedagogy training used in the training of cultural project managers therefore can be grasped in the respect that the teaching and 


\section{Acta Technologica Dubnicae}

volume 1, 2011, issue 2

learning processes used in the dramatic process training are linked to the theatrical form. This relationship is based on a unique paradox. Namely, the training would like to assert both intellectual and emotional influence, much like the theatre. At the same time it strives to maintain an equilibrium in which the teacher-trainer's pre-conceived plans and strategies operate "yet retains the possibility of its spontaneity, the participants' creative role as if they were the 'writers', 'dramaturges' or even 'the director" "(O'Neill - Lambert, 1982). But the biggest contradiction to be bridged is between the artistic impact and understanding the tension between the need for change. Because the training does not want to "dazzle" (Bolton, 1996) or "manipulate" the participants, but it actually wants the participants to be responsibly aware of what is happening to them and to observe themselves from the outside. Not because of someone else's requirements, but because this is not for the viewers to play, not even the trainer, but in order for a deeper understanding to happen. Despite this understanding, such theatrical forms should be offered during the training, which can be of cathartic influence, as Dorothy Heathcote puts it, "acting at the level of the cardia, drama deals with what people digging deep in themselves want to know about what it means being human" (Wagner, 1976). This will require the dramatic theatrical skills.

The theatre "wishes to explore, since ancient times, the nature of the social phenomena what it means to exist as human beings" (Neelands, 1994). The history of modern drama pedagogy carries the same lesson, namely how educational drama managed to find that. How could it distance itself from this very strong base that the past of the theatrical drama meant (Huszár, 1981), creating its own identity in the world of pedagogy, and then return to the same place. Now with an entirely new autonomous identity, inter alia, in the form of the above analysed training show the participants of the learning process the opportunities of "the experience of being human".

\section{References}

BOLTON, G.: A tanítási dráma elmélete. [A theory of teaching drama]. In Színházi füzetek $V$. Theatrical notebooks Sun Marczibányi Téri Müvelödési központ. Budapest: Marczibányi Square Cultural Center, 1996.

FOUCAULT, M.: Polemics and Problematizations. In The Foucault Reader. Ed. P. Rabinov (Paul Rabinov interview). Harmondsworth: Penguin, 1986.

HUSZÁR, Z.: „Igazi” dráma-e a passiójáték? [“Real” Passion in the e-drama?]. In Posztulátum, 1, 1981, pp. 15-25.

KAPOSI, L.: Dramatikus módszerek a bünmegelözés szolgálatában. [Dramatic methods of crime prevention service]. Budapest: The National Crime Prevention Centre and the Hungarian Drama Society, 2004. 


\section{Acta Technologica Dubnicae}

volume 1, 2011, issue 2

NEELANDS, J.: Dráma a tanitás szolgálatában. [Drama in the teaching service]. Budapest: Drama Society and the Hungarian Cultural Center Marczibányi Square, 1994.

O'NEILL, C. - LAMBERT, A.: Drama structures. In Drámapedagógiai Olvasókönyv. [The Practical Handbook for Teachers]. Ed. L. Kaposi. Budapest: Hutchinson Education, 1995.

SZAUDER, E.: Dramatikus eljárások a sérült gyermekek oktatásában és nevelésében. [Dramatic proceedings of the injured children's education and upbringing]. In Drámapedagógiai Magazin, 3, 2001, p. 31.

TELEGDY, B.: A tanítási dráma egy lehetséges tervezési stratégiája. [Teaching drama to a possible design strategy]. In Drámapedagógiai Magazin, 2, 2006.

VÁRNAGY, P.: A hátrányos helyzet pedagógiája. [Pedagogy of the disadvantaged]. Budapest: Corvinus - the seven liberal arts library, 2003.

WAGNER, B. J.: Dorothy Heatcote: Drama as a Learning Medium. London: National Educational Association Publication, 1976.

ZALAY, S.: A drámapedagógiai ihletésủ kommunikációs tréning. [A drama inspired by the communication training]. In Drama Magazine, 3, 2002.

ZALAY, S.: A drámapedagógiai módszer alkalmazása a kommunikációs tréningeken. [The drama of the method of communication training sessions]. In PTE FEEFI Tudásmenedzsment [PTE FEEFI Knowledge Management], vol. 1, 2004, no. 1, pp. 76-88.

ZALAY, S: Konstruktivizmus és drámapedagógia. [Constructivism and drama]. In Iskolakultúra, 1, 2006, pp. 66-71.

ZALAY, S.: A tanulás élménye. [A learning experience]. In Az oktatás közügy. [Education is a public issue]. Eds. A. Benedek - H. Györgyné. VII. Nevelésügyi Kongresszus Zárókötete, pp. 348-354. 